\title{
THE USE OF TOURISM CONSUMPTION ESTIMATIONS TO ASSESS THE ECONOMIC EFFECTS OF TOURISM IN METROPOLITAN CITIES AS EXEMPLIFIED BY WARSAW
}

\author{
EWA DZIEDZIC, ${ }^{1}$ TERESA SKALSKa, ${ }^{2}$ ROBERT VINCZE ${ }^{3}$
}

1 Warsaw School of Economics

Collegium of World Economy

e-mail: edziedz@sgh.waw.pl

2 Warsaw School of Tourism and Hospitality Management

Faculty of Tourism and Recreation

e-mail: t.skalska@vistula.edu.pl

3 Advisory Board Member World MICE Day

e-mail: vincze@won.sk

\section{JEL CODES}

KEYWORDS

ABSTRACT

\section{Z32, L83, R11}

economic impact of tourism, urban economics, tourism expenditure, tourism industries

The article aims to present possible use of tourism consumption estimations for the assessment of the economic effects of tourism in metropolitan cities as exemplified by Warsaw, followed by their application as a support tool for urban development management. Such estimations allowed to assess direct effects in terms of demand generated by tourism, also broken down into major market segments. The comparison of information on trips of residents and non-residents allowed to evaluate which of the main groups of customers played a particularly significant role for producers of tourism services in Warsaw.

The investigation also indicated the possibilities of and limitations on the use of the estimations made for strategic measures, whether taken by the municipal authorities or economic operators. The article points out available sources of information and has identified gaps in that respect.

\section{Introduction}

Recently observed buoyant growth of metropolitan cities as complex economic, social and political systems is accompanied by increasing interest in the role of tourism from policy-makers, business bodies and research centres (Smętkowski, Jałowiecki, Gorzelak, 2009: Zmyślony, 2015; UNWTO, 2012). Metropolitan cities receive major tourist traffic providing substantial value to local communities but that fact and its implications have not been sufficiently addressed in publications 
and studies (Ashworth, Page, 2011). Until lately, cities were mostly perceived as source markets, whereas analyses of cities as tourist destinations mainly discuss social and spatial aspects of the effects of tourism with less attention given to its contribution to the economy. Nevertheless, due to the importance of metropolitan cities to the tourism market, the need arises to better recognise the impact of tourism (UNWTO CICtourGUNE, 2014; WTTC, 2017). The measurement of such effects is not an easy exercise, mostly due to the lack of reliable data. Such impact is primarily measured by the size of demand generated, output, gross value added or GDP, the number of persons employed and tax receipts.

The needs of the authorities of tourist regions, whether at the national, regional or local level, focus on obtaining summarised knowledge regarding macroeconomic indicators. ${ }^{1}$ Vital areas of interest also include the level and structure of tourism employment broken down into types of activity, tourism investment relating to both building the tourism attractiveness of the region and the development of infrastructure used by visitors (also in the breakdown by type of activity) and the share of tourism in local budget expenditure and revenue. The sources of revenue for regional authorities include the share of receipts from personal and corporate income tax, revenue from property tax charged on facilities classified as tourism infrastructure and from the local levies on accommodation services. The regional authorities are interested in establishing the amount of revenue from the above-mentioned taxes and levies as such knowledge facilitates the determination of the overall share of tourism in the regional budget revenue and, in comparison with expenditure, it also allows to specify the contribution of tourism to increasing revenue allocated to other needs of the region.

The presented article assumes that the economic effects of inbound tourism in a metropolis are derived from consumption expenditure made during stays in that metropolis and before such trips on the purchase of services provided by businesses located in the visited area. Tourism consumption in Warsaw was estimated on the basis of receipts from two groups of visitors: residents of other regions of Poland and non-residents from abroad arriving in the city. The estimation relied on the methodology of the tourism satellite account (TSA). It was assumed that - tourism consumption in the metropolis comprised of household consumption, expenditure related to business trips and the consumption of the general government sector and of non-profit institutions, made in the metropolis and for the benefit of the metropolitan enterprises. Such estimations allowed to assess direct effects in terms of demand generated by tourism, also broken down into major market segments. In addition, they enabled estimation of gross value added and employment. The study resulted in the determination of both the level and structure of tourism consumption in the metropolis. The comparison of information on trips of residents and non-residents allowed to evaluate which of the main groups of customers played a particularly significant role for producers of tourism services in Warsaw.

The investigation also indicated the possibilities of and limitations on the use of the estimations made for strategic measures, whether taken by the municipal authorities or economic

1 In addition, it is worth emphasising that such indicators frequently cannot be determined, not only due to difficulties related to the estimation of tourism GDP and value added in tourism but also on account of the lack of GDP and value added estimations for the regional economy. 
operators. In addition, the article points out the available sources of information and identified gaps in that respect. The example of Warsaw was used as - according to the WTTC estimations - in 2006-2016 the city experienced dramatic growth in the contribution of tourism to the economy (by an annual average of 5.7\%), with the rate additionally increasing to ca. 7\% (WTTC, 2018).

\section{Measurement of the economic effects of tourism in metropolitan cities - a theoretical approach}

The economic effects of tourism are usually measured by economic aggregates such as the size of generated demand, output, gross value added or GDP, employment in the sector and tax revenue (Frechtling, 2009; Murillo, Vayá, Romani, Suriñach, 2011; Kauppilaa, Karjalainena, 2012). ${ }^{2}$ Those result from demand created by inbound tourism in a metropolis and by outbound tourism of its residents on the one hand and from the output of enterprises located in the city and demand generated by tourism-related investment on the other hand. Another crucial element is demand created by tourism-related collective consumption, also including public expenditure (Dziedzic, Kachniewska, Skalska, 2016).

All the phenomena described can be examined in terms of overall values or with regard to selected market segments, e.g. the effects of demand by foreign visitors, the effects of sporting events, expenditure on the promotion of the metropolis, etc. (Heeley, 2011). The focus can be on direct effects of consumption expenditure or of investment, indirect effects including the whole production impulse in the region as a result of the aforementioned expenditure or on induced effects, arising from increased consumption of persons earning income from such direct or indirect effects of tourism (Heeley, 2011; Murillo et al., 2011). One method used to measure direct economic effects of tourism which can also be applied to a metropolis is the assessment of revenue from consumption expenditure incurred in connection with trips taken to the destination under analysis. It also enables market segmentation but requires access to reliable data on visitors' expenditure made in the metropolis and on behalf of local enterprises. In addition, the method allows to estimate gross value added and employment, on the assumption of the availability of supply-side data, mostly derived from public statistics.

As regards the demand side, metropolitan cities face two large flows of tourist traffic affecting their economies: inbound and outbound tourism. In the case of inbound tourism, it includes travel for virtually all personal purposes, i.e. leisure, visiting relatives and friends, education, health, religion, shopping and transit, and business purposes, including participation in conferences, trade fairs, etc. (Law, 2002; Mika, 2011; Edwards, Griffin, Hayllar, 2008). The travel purposes has specific implications concerning the seasonality of visits, their weekly and daily distribution, places visited, types of activity during the stay in the city and thus the amount and structure of travelrelated expenditure. It is worth pointing out that a great number of trips are generated somewhat autonomously as a consequence of the functions of metropolitan cities (business trips to administrative and production centres, engaging commercial and medical service providers, family visits,

2 Most frequently, the effects are analysed as net budgetary effects, i.e. receipts from taxes and levies less subsidies. 
etc.), whereas only part of tourist traffic can be actively promoted through marketing activities. The above applies to trips taken for broader experience and entertainment purposes, to participate in congresses, trade fairs and possibly health and education travel.

The technological advancement in IT services, improved access to transport services and new social phenomena have all considerably influenced tourism in metropolitan cities. The consequences of the aforementioned changes include the rise of the sharing economy posing certain competition to economic operators, changed ways of using goods and services offered by the city, i.e. switching from traditional sightseeing to participation in urban life (Bock, 2015; Ashworth, Page, 2011; Mika, 2011), and an increased importance of same-day visits (Murillo et al., 2011).

The economic effects of inbound tourism arise from consumption expenditure made not only during the stay in the metropolis but also before arrival, insofar as such expenditure comprises the purchase of services supplied by businesses located in the metropolis visited. Traditionally, the main sources of relevant information were surveys conducted at accommodation facilities (Heeley, 2011); however, those produced no satisfactory results as they excluded demand from same-day visitors, persons visiting relatives and friends and guests of non-registered accommodation facilities, also as a part of shared consumption. An alternative solution allowing to avoid such problems is to survey visitors in their places of residence. Whereas such a solution seems effective in the case of domestic tourism, it is impracticable with regard to inbound travel. Therefore, relevant data are usually gathered as part of surveys of foreign inbound visitors in the country concerned. Such a data collection method proves effective with regard to overall tourist traffic and expenditure but obtaining information on purchasing behaviour patterns in particular market segments requires a considerably increased sample, otherwise such estimations are significantly biased (UNWTO InRouTe, 2015). For that reason, a number of metropolitan cities decide to carry out their own field surveys, which entails preparing appropriate survey patterns regarding the timing and places of conducting interviews (Szafrańska, Włodarczyk, Dziedzic, 2015, pp. 51-62). It must be taken into consideration that particular categories of visitors may appear only in certain types of places, therefore the spatial structure of places surveyed may affect the survey results. To recapitulate, on the demand side it is possible to rather precisely determine the scope of tourism (inbound and outbound traffic), whereas it is more difficult to gather relevant data.

\section{The level and structure of tourism consumption in Warsaw in 2014 and 2016 : the estimation results}

The above-mentioned difficulties involved in the assessment of the economic impact of tourism occurred in estimations of tourism consumption for Warsaw in 2014 and 2016. In the case of the consumption of residents (inhabitants of Poland visiting Warsaw), it proved necessary to make appropriate estimations on the basis of different information sources. As the main sources used, the results of field surveys conducted in Warsaw in 2014 and $2016^{3}$ served to estimate the number of arrivals of tourists in both years and that of same-day visitors in 2014 as well as the amount of ex-

3 Surveys commissioned by the Warsaw Tourist Office (Stołeczne Biuro Turystyki); for 2016, the number of sameday visits was estimated on the basis of the omnibus survey conducted among Polish residents. 
penditure incurred in the metropolis. As regards expenditure, it was determined from the field survey questionnaire concerning planned expenditure in Warsaw (i.e. expenditure on accommodation, food- and beverage-serving services, cultural services, local transport, shopping, etc., but with no possibility to break it down into categories). Due to the lack of information on the structure of the expenditure by type, it was imputed with the use of data on short-stay domestic trips available in the EUROSTAT database. ${ }^{4}$ Expenditure on transport, both to and within Warsaw, was estimated separately from data on the transport mode obtained from the field survey. It must be noted that data on the consumption of transport services only covered the consumption of services provided by enterprises registered in Warsaw.

In 2016, tourism consumption in Warsaw was ca. PLN 7.6 billion, 51\% more than two years before (cf. tab. 1), more than half of which is attributable to visits by Polish residents. It is worth pointing out that in comparison with 2014 the share decreased in favour of expenditure by nonresidents from abroad. The tourism consumption estimated for Warsaw cannot be compared to the respective values for Poland as a whole, obtained in the TSA, as it was not prepared for either 2014 or 2016.

Table 1. Tourism consumption in Warsaw in 2014 and 2016 (PLN million)

\begin{tabular}{|c|c|c|c|}
\hline Products & 2014 & 2016 & 2016:2014 \\
\hline Accommodation services & 869 & 1,064 & 1.22 \\
\hline Food- and beverage-serving services & 1,873 & 2,979 & 1.59 \\
\hline Passenger rail transport services, interurban & 329 & 722 & 2.19 \\
\hline Other passenger land transport services & 470 & 260 & 0.55 \\
\hline Passenger air transport services & 454 & 941 & 2.07 \\
\hline Services incidental to air transportation & 73 & 157 & 2.15 \\
\hline Travel agency, tour operator and other reservation services and related services & 116 & 201 & 1.73 \\
\hline Library, archive, museum and other cultural services and sporting services & 540 & 667 & 1.24 \\
\hline Tourism products, total & 4,724 & 6,993 & 1.48 \\
\hline Retail trade services (retail trade margin) & 295 & 575 & 1.95 \\
\hline Total & 5,019 & 7,568 & 1.51 \\
\hline
\end{tabular}

Source: authors' study.

The most important item in the group of tourism-characteristic products purchased in Warsaw by visitors (both tourists and same-day visitors) were services related to subsistence (food and beverages); it is worth stressing that their share in total consumption increased from $37.3 \%$ in 2014 to $39.4 \%$ in 2016. It is connected with a high number of same-day visits of Polish residents, using services supplied by food and beverage serving establishments during their stay in Warsaw, as well as with growing interest from tourists in regional cuisine. At the same time, accommodation services, provided by both hotels and other accommodation establishments accounted for $14.1 \%$ of total consumption in 2016, a proportion 3.3 pp lower than in 2014. When discussing the composition

4 Average expenditure per trip by expenditure categories (from 2012 onwards) [tour_nat_expert], http://ec.europa. eu/eurostat/data/database, accessed on 23.06. 2017 (the most recent data concerning 2015 were used for 2016). 
of tourism-characteristic products, it is also worth pointing out that expenditure on air transport services and services incidental to air transportation more than doubled (fig. 1).

At the same, the comparison of expenditure of residents and non-residents allows to evaluate which of the main groups of customers plays a particularly significant role for producers of tourism services in Warsaw. In 2016, it is worth noting the importance of residents' households as customers of food and beverage serving establishments and recipients of passenger land and rail transport services; they consumed, respectively, 58.6\%, 69.2\% and $91.7 \%$ of the services indicated above. The comparison of data for 2014 and 2016 shows a distinct domination of demand from residents with regard to food- and beverage-serving services, although with a weakening trend (in 2014 , the share of residents' expenditure on food- and beverage-serving services was $60.7 \%$, in $2016-58.6 \%)$.

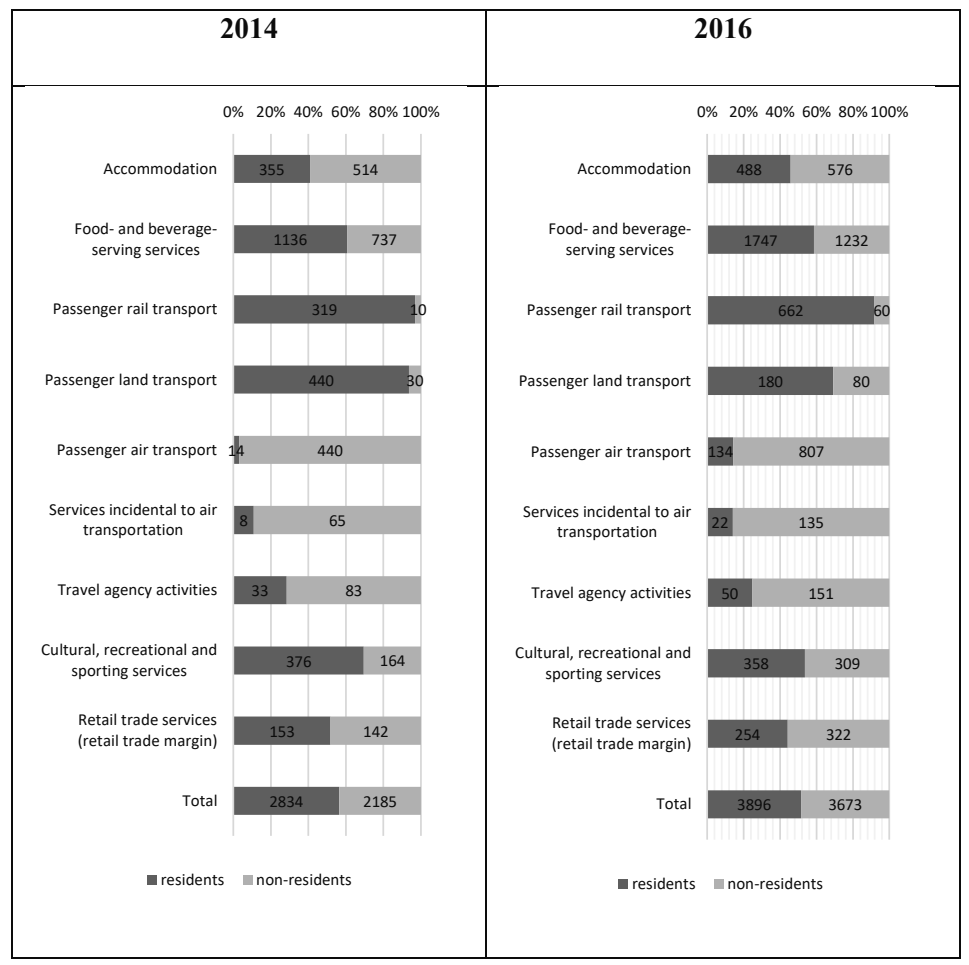

Figure 1. Tourism consumption in Warsaw by category of products and group of customers in 2014 and 2016 (million PLN)

Source: authors' study.

Such a considerable proportion must be attributed primarily to a great number of same-day visits of residents. As regards air transport services, services incidental to air transportation and broader travel agency activities (i.e. travel agency, tour operator and other reservation services 
and related services), expenditure by foreign nationals played a dominant role. The significance of air transport results not only from different features of tourist traffic, characteristic of a large city, arising from factors such as a major share of business tourism, but also from the location of Poland's largest international airport. Simultaneously, in 2016, travel agency and tour operator services were purchased in nearly $75.2 \%$ by non-residents (in $71.5 \%$ in 2014 ).

To recapitulate the results of estimations of tourism consumption in Warsaw in 2014 and 2016, it is worth pointing out its different structure in comparison with that estimated for the country (but it must be remembered that it is solely possible to make references to estimations for the whole Poland from 2013 and 2015). In Warsaw the composition is more favourable for the tourism sector than in the case of Poland as a whole. The different structure of expenditure results from a number of factors such as:

- a major share of expenditure incurred by non-residents from abroad,

- a significant proportion of expenditure by persons travelling on business (both residents and non-residents), typically spending more per trip,

- the location in the capital city of the largest international passenger airport and of operators providing services incidental to air transportation,

- a greater share of same-day visits of Polish residents who generally declare the use of food and beverage serving services,

- and - which is certainly not irrelevant but was not analysed in proper detail - a higher level of prices for tourism services, both in the hotel industry and at food and beverage serving establishments.

\section{The use of estimations: possibilities and limitations}

When commenting on the results of estimations and their possible use, one must identify the actual tourism policy needs - on the one hand and present statistical limitations - on the other hand. It is worth emphasising that tourism is a regional phenomenon; in that context, regional statistical information is a pre-requisite for estimations of the impact of tourism on the regional/urban economy, followed by actions undertaken in tourism policy and overall economic policy concerning that area. A major role may be played by regional tourism satellite account (RTSA). The priority is to determine consumption in the region where it actually took place. With regard to tourism consumption, employing the concept of RTSA at the agglomeration level assumes that the terms used are equivalent to those applied at the national level, only the reference area is the metropolis concerned. It must be assumed that every region is treated as a separate, strictly specified and economically defined entity, which means that all transactions with other regions must be registered as transactions with the 'rest of the world'. For the region concerned, the 'rest of the world' includes not only other countries but also the rest of the national territory, i.e. other regions of the country in question. ${ }^{5}$

5 The necessity to adapt the TSA to regional needs is pointed out, inter alia, by P. Laimer, Regional Tourism Satellite Accounts in Austria - sufficient information for regional tourism policy? $11^{\text {th }}$ Global Forum on Tourism Statistics, November 2012, Reykjavík, Iceland. 
In tourism policy, reliable data for regions cannot be overestimated as decisions concerning both tourism promotion and tourism investment are mostly made at the sub-regional level, in tourist regions usually delimited on the basis of the existing administrative units. The results of national and regional TSA are generally used and commented on by various public and private entities: national and regional authorities engaged in the tourism sector, national and regional tourism organisations, national and regional entities responsible for public statistics, the central bank, business and tourism associations, academic and research institutions, international organisations and non-governmental organisations active in tourism. The development and implementation of selected methods of assessing the impact of tourism on the regional economy certainly supports policy-making with regard to development strategies, by supplying policy-makers with data allowing to understand the size and importance of tourism and its position in the regional economy. Such information can foster new tourism policy initiatives and the distribution of available subsidies. Having suitable and proven methods as well as reliable data should be conducive to optimal decision-making strengthening tourism development and contribute to the maximisation of benefits derived from that industry. In practice, estimations based on the methodology of TSA can serve as a framework for investigating the impact of tourism on regional development, analysing changes, measuring efficiency, thus as the basis for shaping tourism policy. They provide policy-makers with insights into tourism, its functions and socio-economic effects, they allow for indicating production functions of the tourism industry and illustrating links between the tourism industry and the rest of the economy. They demonstrate that tourism is much more than 'accommodation' and 'food and beverage serving services'. Figures shaping and fostering awareness help to increase funds of local authorities and reasonable support for the sector. Consumption analysis provides information on the composition of the main groups of customers: households, non-residents, corporate employees. Importantly, it shows items purchased by users and industries benefiting the most from those purchases.

However, being a macroeconomic tool, it is primarily used at the national level. With regard to regions, its value and usefulness largely depend on the availability and quality of data for the regions under analysis, on the application of reliable estimation, modelling and extrapolation methods. At the metropolis level, it is a difficult but not impossible exercise; it certainly requires cooperation between regional statistical offices, municipal authorities and research institutions. This also - or primarily - concerns surveys of demand which, if available, are usually not very recent, characterised by excessive aggregation, rarely conducted, frequently on the basis of irregular, oneoff surveys.

\section{Conclusions}

The actual scope of measuring the economic effects of tourism depends on the needs related to urban development management, the stakeholders' interests and objective possibilities linked with the application of specific measurement methods (Heeley, 2011, pp. 53-54). Information on the economic effects of tourism may be required in connection with various stages of the urban 
management process. In the case of tourism, they may primarily concern strategic planning, with regard to both the role of tourism and specific tourism development orientations, organisation and decision-making (including the allocation of funds, the distribution of decision-making powers) and the control stage (Markowski, 1999, pp. 15-16). Obtained information can be used to monitor tourism development, within internal benchmarking (tourism development, tourism versus other economic activities) as well as, if possible, external benchmarking (Heeley, 2011, p. 54; Kozak, 2004). Making such use of the measurement results depends on the consistency of data used and methods employed in dynamic terms (internal benchmarking) and in spatial terms (external benchmarking). Therefore, data obtained within the framework of standard public statistics programmes and administration data are of particular value. An important merit of information reflecting the size of tourism consumption as a measurement method is the possibility of illustrating the level and structure of all items of expenditure recognised as tourism-related, including expenditure incurred by same-day visitors, i.e. excluded from statistics concerning accommodation. On the other hand, however, tourism consumption only comprises the value of direct contribution of tourism to the economy. Considering direct relationship between the visitor and the producer, such an approach excludes various indirect and induced effects of tourism demand arising from linkages within the economy.

As indicated above, it is difficult to empirically estimate the value of consumption due to strict requirements as to the scope and granularity of data. During estimations, the needs resulting from methodological assumptions may clash with statistical reality.

\section{Acknowledgement}

The data concerning Warsaw have been obtained as an outcome of the research funded by the Government of the Capital City of Warsaw.

\section{Refeprences}

Ashworth, G., Page, S. (2011). Urban tourism research: Recent progress and current paradoxes. Tourism Management, 1 (32), 1-15.

Bellini, N., Pasquinelli, C. (eds.) (2016). Tourism in the city. Towards an integrative agenda on urban tourism. Springer.

Bock, K. (2015). The changing nature of city tourism and its possible implications for the future of cities. European Journal of Futures Research, 3-20.

Canada, A. (2013). Regional Tourism Satellite Account. Madrid: UNWTO.

Dębski, M., Dziedzic, E., Skalska, T., Zawistowska, H. (2017). Wpływ turystyki na gospodarkę Warszawy. Stowarzyszenie na Rzecz Badania, Rozwoju i Promocji Turystyki. Praca wykonana na zlecenie Stołecznego Biura Turystyki. Retrieved from: http://warsawtour.pl/wp-content/uploads/2018/03/Wplyw_turystyki_na_gospodarke_ Warszawy_w_latach_2014_i_2016.pdf.

Dwyer, L., Forsyth, P., Dwyer, W. (2010). Tourism Economics and Policy. Buffalo-Bristol-Toronto: Channel View Publications.

Dziedzic, E., Kachniewska, M., Skalska, T. (2015). Rachunek satelitarny turystyki: metodologia, wyniki, interpretacja. Warsaw: Szkoła Główna Turystyki i Rekreacji.

Dziedzic, E., Kachniewska, M., Skalska, T. (2016). Regionalny rachunek satelitarny turystyki: metodologia, uwarunkowania implementacji. Warsaw: Szkoła Główna Turystyki i Rekreacji. 
Edwards, D., Griffin, T., Hayllar, B. (2008). Urban Tourism Research. Developing an Agenda. Annals of Tourism Research, 4 (35), 1032-1052.

Eurostat. Retrieved from: http://ec.europa.eu/eurostat/data/database (23.06.2017).

Eurostat (2016). Urban Europe. Statistics on cities, towns and suburbs. Louxemburg: Eurostat.

Frechtling, C. (2009). Measurement and analysis of tourism economic contributions for sub-national regions through the Tourism Satellite Accounts. Madrid: UNWTO.

Heeley, J. (2011). Inside city tourism. A European perspective, Bristol-Buffalo-Toronto: Channel View Publications.

Kauppilaa, P., Karjalainena, T. (2012). A process model to assess the regional economic impacts of fishing tourism: A case study in northern Finland. Fisheries Research, 127-128, 88-97.

Kozak, M. (2004). Destination benchmarking. Concepts, practices and operations. Wallingford, Cambridge: CABI Publishing.

Law, C. (2002). Urban Tourism. The Visitor Economy and the Growth of Large Cities. London: Continuum.

Markowski, T. (1999). Zarządzanie rozwojem miast. Warsaw: Wydawnictwo Naukowe PWN.

Mika, M. (ed.) (2011). Kraków jako ośrodek turystyczny. Cracow: Instytut Geografii i Gospodarki Przestrzennej UJ.

Murillo, J., Vayá, E., Romani, J., Suriñach, J. (2011). How Important to a City Are Tourists and Daytrippers? The Economic Impact of Tourism on The City of Barcelona. Barcelona: AQR-IREA Universitat de Barcelona.

Ritchie J., Crouch J. (2003). The Competitive Destination. A Sustainable Tourism Perspective. Cambridge: MA CABI Publishing.

Smętkowski, M., Jałowiecki, B., Gorzelak, G. (2009). Obszary metropolitalne w Polsce - diagnoza i rekomendacje. Studia Regionalne i Lokalne, 1, 52-73.

Szafrańska, E., Włodarczyk, B., Dziedzic, E. (2015). Pomiar wielkości ruchu turystycznego w regionie. In: E. Dziedzic (ed.), Badania konsumentów usług turystycznych w regionach (pp. 51-64). Warsaw: Polska Organizacja Turystyczna.

UN, UNWTO (2008). International Recommendations for Tourism Statistics 2008 (IRTS 2008). New York-Madrid: UN, UNWTO.

UNWTO (2012). Global Report on City Tourism - Cities 2012 Project (AM Report $n^{o}$ six). Madrid: UNWTO.

UNWTO, CICtourGUNE (2014). For City Tourism Measurement. Global Benchmarking. Madrid: UNWTO.

UNWTO, InRouTe (2015). A Closer Look at Tourism: Subnational Measurment and Analysis. Subnational Tourism: a Basic Glossary. Madrid.

Williams, S., Lew, A.A. (2015). Tourism Geography, Critical Understanding of Place, Space and Experience. London, New York: Routledge.

WTTC (2017). City Travel \& Tourism Impact 2017 Europe.

Zmyślony, P. (2015). Funkcja turystyczna w procesie internacjonalizacji miast. Poznań-Cracow: Proksenia. 


\section{WYKORZYSTANIE SZACUNKU KONSUMPCJI TURYSTYCZNEJ JAKO MIERNIKA EFEKTÓW EKONOMICZNYCH TURYSTYKI W MIASTACH METROPOLITALNYCH NA PRZYKŁADZIE WARSZAWY}

\author{
SŁOWA KLUCZOWE \\ STRESZCZENIE
}

ekonomiczne efekty turystyki, ekonomia miast, wydatki turystyczne, branże turystyczne

Celem artykułu jest prezentacja potencjalnego wykorzystania szacunku konsumpcji turystycznej efektów ekonomicznych turystyki w miastach metropolitalnych na przykładzie Warszawy, a następnie zastosowania go jako narzędzia wspomagającego zarządzanie rozwojem miasta. Taki szacunek umożliwia określenie bezpośredniego efektu jakim jest popyt generowany przez turystykę, a dodatkowo jego strukturę według głównych segmentów rynku. Porównanie informacji o podróżach rezydentów i nierezydentów pozwoliło ocenić, która z głównych grup nabywców odgrywają szczególną role z punktu widzenia producentów usług turystycznych w Warszawie. Badanie wskazuje ponadto możliwości i ograniczenia zastosowania tego typu szacunku dla zadań strategicznych, podejmowanych przez władze miasta lub podmioty gospodarcze. W artykule wskazano dostępne źródła informacji i zidentyfikowano luki w tym zakresie. 